\title{
Improving Interactive Teaching Strategies: Action Research with a Life Skills Teacher in Oman
}

\author{
Ziyana Salim Al Harthy, , Suhailah Hussien ${ }^{\text {, }}$, Hamoud Bin \\ Khalfan Al Harthyc
}

\begin{abstract}
Considering Oman's engagement in educational reforms that are aimed at improving the educational system to fit the needs and challenges of globalization and the current emphasis on the application of Interactive Teaching Methods (ITMs), this study sought to explore the experiences of Living Skills teachers in engaging in AR to improve Interactive Teaching Strategies (ITSs). It explores the experience of an Omani Life Skills teacher's involvement in the participatory process of guided Action Research (AR) to improve her Interactive Teaching Strategies (ITSs). Focus is on how this involvement helped her improve her teaching as well as her views and understandings of Interactive Teaching Methods (ITMs). The findings indicate that the teacher was able to accomplish a good transformation of her understanding in some of Interactive Teaching principles and better application in her teaching while highlighting the barriers to the implementation of AR, such as lack of support, poor resources, and time constraints. These findings are hoped to contribute to efforts for developing better and focused teacher training methods for IT and AR support and implementation in Oman.
\end{abstract}

Keywords: Interactive Teaching Strategies; Life Skills; Action Research; Interactive Teaching Methods; Education in Oman

\section{Introduction}

In the Omani educational system, the philosophical transformation of teaching and learning to a learners' centred approach corresponded with the introduction of the new subject, Life Skills (Living Skills) and the learner centred principles (Ministry of Education [MoE], 2004a). Teachers were expected to transform themselves, especially given that Living Skills Based Education emphasizes the adoption of Interactive Teaching and Learning (IT\&L) through Interactive Teaching Methods (ITMs) (UNESCO, 2008).

Effective learning involves the interaction among learners who have various learning styles; teachers using different teaching methods; and contents. Failing to adequately implement the teaching methods could lead to failure of attaining the right skills development and achieving the targeted educational

a Ministry of Education, Oman

b Kulliyyah of Education, International Islamic University Malaysia

c. Ministry of Education, Oman 
goals (Sahlberg, 2008). Accordingly, Gordon, Kane and Staiger (2006) believed that "without the right people standing in front of the classroom, school reform is a futile exercise" (p. 5). Brown (2005) assumed teachers are the core element required to facilitate the learning processes.

The Omani Ministry of Education has changed its policy, calling for the transformation in teaching methods and the resulting demands for in-service training and professional development. It examines the implementation of the policy to transform education to a learner centred approach through the Living Skills subject from both the practical and the theoretical perspectives. Moreover, the personal professional development (PPD) associate with this shift is also examined in order to better understand what actually transpires on the ground, its shortcomings and how it can be improved. Hence, a special focus is awarded to the PPD component to improve Interactive Teaching Strategies (ITSs). It is hoped that this research will facilitate the achievement of the reformed educational goals set by the Omani MoE.

In spite of the numerous calls to adopt ITMs in Omani schools, there remain weaknesses as documented by a number of researches (Al-Nofli, 2010; Al-Jadidi, 2009; Al-Harthy, 2008; Al-Sarmi, 2004; Al-Aghbari, 2001). AlJadidi (2009) reported on the teacher-centeredness of some English lecturers in education institutions in Oman. The characteristics reported were that lecturers exerted strong control through the lesson; they did not give the learners' an opportunity to talk, and contribute to their own ideas. The lecturers did not take any account of any individual learning needs. Furthermore, group learning was less adopted and focused on individual learning and whole class discussions on account of group. Al-Nofli (2010) identified that geography teachers of cycle two basic education adopted the lectures mode of instruction and often had learners copying from the board. Although the study of Jadidi and AlNofli presented different fields of learning and different level of teaching organizations but it presents the type of teaching practiced in the teaching organizations. These weaknesses include the teaching of Living Skills. The EFA: Year 2000 Assessment Report claimed that Living Skills are still taught in a traditional teacher-centred approach of 'talk and chalk' (UNESCO, 1999). This is further supported by the report of Al-Lamky (2007), Creative Associates International, Inc. (2006) and my personal observations while on field visits to observe the implementation of the curricula. Al-Hinai (2007) affirmed that the teacher-centred approach based on lecturing and reading from a book is still a common or preferred methodology in many Arab schools. Recently, Faour (2011) claimed that teaching in most Arab countries remains teacher-centred and fails to nurture critical thinking. In addition, Arab schools often lack qualified teachers and most of those presently employed receive poor wages and limited chances for professional development.

The traditional teaching approach achieves poor learning outcomes (World Bank, 2006; Boler \& Aggleton; 2005; UNESCO, 1999) and learners lose interest in the subject (Al-Nofli, 2010). Although Al-Nofli (2010) reported positive results for the ITMs employed in teaching geography, in many cases learners reported unacceptable traditional forms of teaching which they did not enjoy. The UNESCO report (1999) is the only official report for the teaching of Living Skills, conveyed a poor learning outcome for grades 1-4. Moreover, learners in Omani schools would informally comment that learning Living Skills is boring because the teacher made them read from the book and failed 
to provide opportunities for practical implementation. Batool has supported this claim during the post interview.

\section{The Present Study}

This study aimed to address the problematic implementation of ITSs and marginal participation in AR. It reflects the need to engage Living Skills teachers in AR as an IT approach to help them improve their implementation of ITSs and make them appreciate the process as PPD. To do so I considered exploring and studied the participants' experiences of the two aspects of ITSs and AR in the instruction of Living Skills qualitatively. The first aspect investigates how teachers understood IT and evaluated their own ability to apply ITSs before and after AR. The second aspect examines how participants perceived the challenges of engaging in AR and how it influenced their application of these strategies and their future vision of taking AR as a PPD activity.

Thus, this study was approached through PAR to engage teachers in $\mathrm{AR}$ and phenomenological exploration of their experiences in understanding ITSs, and enacting both the ITSs and AR to improve their application of ITSs associated with teaching methods in Oman. "Action Research," according to Johnson (2008), " does not mean that you have to prove something....It is often conducted simply to find what's going on.... the goal is to understand, evaluate, or even to find new ideas and see how they work" (p. 62). Engaging them in AR as an interactive method is expected to influence their teaching styles as the way they taught to likely be the way they will teach. The second reason is the position of the Islamic world view which emphasises that in order for a person to transform there is a need for the individual to take personal initiative to change. This is supported by many educational scholars. Ferrance (2000) sees that:

Action Research is not about doing research on or about people, or finding all available information on a topic looking for the correct answers. It involves people working to improve their skills, techniques, and strategies... is not about learning why we do certain things, but rather how we can do things better. It is about how we can change our instruction to impact students (p. 2 \& 3).

The most recommended approach for in-service teachers training to meet classroom challenges is encouraging them to be reformers themselves through AR (Johnson, 2008; James, Milenkiewicz \& Bucknam, 2008; Brown, 2002; Goodnough, 2001). Therefore, in circumstances similar to that of in-service Omani Living Skills teachers having problems in the implementation of ITM's, I believe that AR could be among the best solutions especially since reflection is part of the belief system of the selected teachers.

This study employs Participatory Action Research (PAR) as a means to develop teachers who are willing to improve their teaching practices as recommended by Denzin and Lincoln (2000) and Merriam (1998). It attempted to answer the following questions: (1) How does AR influence teacher's understanding and implementation of ITSs? (1a) What are teacher's views and perceptions toward ITSs before and after engaging in AR? (1b) How do the teacher implements ITSs before and after engaging in AR? (2) 
What are the challenges that the teacher faced while engaging in AR? (3) What are teacher's perceptions toward AR after going through it?

\section{METHOD}

This study investigated an Omani Living Skills teacher teaching grades 5-10 in a government school engaging in AR to improve her application of ITMs. The participant is given pseudonym and assigned with a name of "Batool"; she is working in a school located in Dakhiliya region in Nizwa district with a population of approximately 785 learners.

Written bio-data from Batool was obtained. She is a Home Economics graduate of Sultan Qaboos University and has over fifteen years of teaching experience. She started out teaching Home Economics for 10 years and was later transferred to teach Living Skills in the Basic Education School where she still works. She carries the responsibility of teaching grades from 5-10 in 20 lessons per week besides other school activities and tasks. The lesson duration is 40 minutes.

Her outstanding efforts have been recognized by the school principal and the First Regional Supervisor. They credit her with being a good teacher, hardworking and interested in learning. Her interest to engage in this study was evident from the start of the project. She was open to learning and accepting advice that helped support her improvement. The case was selected because it was informative. Batool had problems and was willing to participate (Greenwood \& Levin, 2007; Coghlan \& Brannick, 2005; Denzin \& Lincoln, 2000). Hence, the case of this study was purposefully selected based on the supervisor's recommendation and participant's interest in improving her skills which assists in determining, comprehending, and gaining rich information (Merriam, 1998).

Data collection was by means of document analysis, semi-structured interviews, observation and teacher self evaluation. Most of the lessons observed were in the classroom with the exception of few from the resources centre and school ground. The resource centre is a big hall located within the school and acts as a library and a place where teaching and learning can take place. It is equipped with educational materials, equipment and devices.

\section{Procedure}

The research fieldwork was conducted in three stages: pre-intervention, intervention and post-intervention. The pre-intervention process focused on the administrative work that prepared participants for AR and the application of pre-instruments for confirming the status of participants' experiences with both dimensions of the study. At this stage there were six participants as I proposed at the beginning of the study. The pseudonyms of the selected participants are Batool, Fatma, Farah, Zeina, Sahar and Sumaya. They all went through the Interview and Teacher Self Evaluation instruments. However, Fatma, Farah dropped after this process and did not go on for the observations.

The intervention stage was planned to train the participants and guided them through the AR process so as to improve their ITSs in the teaching of Living Skills. However, half way through the intervention, the rest of the participants dropped and left Batool as the only case in the study. The final post-intervention stage is a collection of Batool's perception on doing AR and 
its influence on instructional skills and understanding of. The field research further continues to report on Batool's progress as a post-AR process and her unguided application of ITSs.

\section{RESULTS AND DISCUSSION}

This study looked at two aspects, namely: (1) the teacher's experience with the implementation of AR to improve her IT instructions and (2) how going through AR has helped the teacher in her professional development of IT instruction. Hence, this chapter analyses the data collected during the following three stages: the pre-intervention, intervention and the post intervention. The analysis conducted and the findings presented in this study only focus on Batool's experience. The other participants were not reported as they dropped out at an early stage. Therefore, there was no in-depth study about their experiences and the data obtained did not contribute to a deep understanding of their lived experiences as phenomenology case studies require.

Although this study is based in the Omani context of Living Skills teachers in the Dakhiliya region, teaching grades 5-10, it provides valuable in-depth information of a teacher's practice with IT and engagement in AR. Hence, this chapter discusses Batool's experiences with the implementation of AR to improve IT instructions as a result of going through the process.

It compares between two stages of her experience with understanding and implementation of IT before and after engaging in AR as a means to improve her ITSs. This is the first main theme that will be discussed as well as subsequent sub-themes. The second aspect is about Batool's perception and views toward $\mathrm{AR}$ and the challenges she faced as she went through this process. This is the second main theme with sub themes appearing under it. Finally, the last section will include the recommendations and the contributions of the study.

The intervention observations and the two post intervention instruments show improvements in Batool's understanding and application of IT compared to her situation in the pre-intervention phase. Her experiences reveal the positive aspects of engaging in AR despite the various challenges encountered by her.

\section{Teacher's experience with Interactive Teaching}

In this section, we discuss how Batool understood and implemented ITSs before and after she engaged in AR. Her implementation of ITSs has changed for the better. The discussion is based on the sub themes, interactive instruction and self learning, group learning and teaching through authentic experiences. This will be presented under each main theme.

\section{Understanding of IT}

Teachers' perception influences their stands and thoughts and consequently guides their actions. This notion comes through in this study where Batool experienced a shift in perception in her own methods of teaching. Her understanding of the general principles of Interactive Instruction specifically through teaching "Practical Application" was reflected in how she interacted with her students and conducted her classes overall. These changes were recognized by Batool herself. I also observed these changes as Batool progressed in her performance of IT in the class. 
Brooks and Brooks (1993) state that in constructivism "teachers are mediators of students and environments, not simply as givers of information and managers of behaviours" (p. 1). Moyles et al. (2001) reported a similar finding in their study with teachers teaching literacy in UK. The teachers in their study, although not fully understood the IT concept, were able to transform their practices of IT to a wider scope. In this research too, the transformation of the concept of IT with Batool shifted from mainly using different teaching approaches to support her in presenting information in the class, to considering learners' active participation and her guiding the learning process. Hence, she transformed her methods of teaching and learning to a more active and interactive process. When she engaged the learners in practical learning she was using an active discovery teaching method, when she allowed learners to work in a cooperative atmosphere she used the probe method of questioning to encourage discussion. Batool recognised the importance of the learners' active role in the teaching/learning process.

The concept of discovery through Self Learning was acknowledged as an element of IT at the pre-intervention phase; however, she was reporting what was presented in the teacher's guide and had not deeply articulated it or conceptualized it. This inference is supported by the pre-observation debriefing sessions. When I pointed out that she was not employing Self Learning. She revealed that she does employ Self Learning by asking learners to read from the book and as I ask them to convey their understanding and bring the information from home. Post Intervention findings supported this claim, the teacher had previously maintained that prior to the intervention she had thought that Self Learning is only when a teacher present learners with questions and expects them to find the answers by themselves and to bring it to the next class. But now she understood that Self Learning is about learners engaging independently from a teacher's dictation, exploring of information and learning through discovery process. Hence, the concept of Self Learning was better understood and practiced by Batool towards the end of the project in comparison to the pre-intervention stage.

Although she did not fully present the elements of Self Directed Learning as enunciated by Knowles for whom Self Learning is "a process in which individuals take the initiative, with or without the help of others, to diagnose their learning needs, formulate learning goals, identify resources for learning, select and implement learning strategies, and evaluate learning outcomes" (1975, p.18). Batool identified and implemented a learning approach in order to engage learner according to his/her ability in learn in general, skills, attitudes, values and knowledge and not only as a method for acquiring information. Hence, she presented Self Learning to its minimum vision according to Omani educational system is calling for to working under the concept of LearnerCentered Approach (MoE, 2004a). The Ministry of Education is aiming at providing learners with opportunities to develop skills for lifelong learning which being self regulated learners is part (MoE, 2004a).

Batool's understanding of Group Learning based on IT, has featured with inclusion of some new elements concerning group work which involved learners taking turns in these responsibilities and the aim of working in groups viz. "sink together or saved". However, when she reviewed on her role on managing group learning at both stages she thought that she should not focus her attention on an individual learner but on the group as a whole. At the post- 
intervention phase she added that she only intervened at the end of the group work that the learners are involved in and only when there was a common mistake. This kind of perception by itself can have a negative impact on learners' learning if it turns into practical action. Postponing in feeding back especially for struggling and less provoked learner could cause frustration and harm their learning process.

Another issue is that she viewed her role as just giving instructions and circulars and no acknowledgment of providing constructive support. Constructivism recognizes teacher's role as being a facilitator and supporters of learners as they experience difficulties during the learning process. In the postintervention phase she still did not acknowledge teacher's role in scaffolding, as she mentioned that teacher's role is about presenting the learning activities and give instructions. Hence, she missed recognizing the right role of a teacher in scaffolding learners in both stages. Consequently, the narrow perspective she had negatively impacted her role as a scaffold person and facilitator.

In respect to experiential learning, which is mainly concerned with Authentic Learning, Kolb, Boyatzis and Mainemelis (2000) basically see it as the basis for the learning process. They believe that the learning process revolves around four activities that learners should go through as they learn: (1) actively engaging in real learning contacts; (2) reflecting on the learnt experience; (3) applying inductive reasoning; analyzing, understanding, explaining and incorporating what was learnt into logical theory that guides action; and (4) finally considering ways of transforming what was learnt into action.

Batool's conception of the profound effect of teaching through authentic experiences was consistent in the two instruments, the interview and teacher's self evaluation at both stages. The understanding of authentic experiences was well articulated by Batool throughout the study. At the pre-intervention phase she presented the meaning of authentic experiences and considered it as those lived experiences relating to learners' life. At the post-intervention phase she presented similar understandings, except that she linked it with their future life and viewed them as being an important element of connecting classroom learning to real life. Her understanding is supported by Lombardi (2007) who considered authentic learning experiences as being the learning experiences and the learning environments that are representing real world events or similar to real world application.

\section{Implementation of ITSs}

Perception is vital in a teaching and learning condition because it supports teachers' choice on how to deal with classroom episodes. Misunderstanding or not understanding the principle of instructions employed in teaching has drastic impact in enacting them (Bulunuz \& Jarrett, 2010; Yilmaz, 2008; Blanchard, 2006; Windschitl, 2004).

The two notions of cause and effect presented in the above statements are reflected in the coming discussion. Although the intervention period was not very long, the changes can be observed in her teaching style and themes emerged under the Interactive instruction, Self Learning, Group Learning and Authentic Experiences. The Interactive Instruction of "Practical Application" based on discovery was the best developed. However, I consider the changes 
to be unstable during the intervention mainly in Group Learning. Batool was struggling in her effort to switch to a more learner-centered approach especially for the part of learners doing the demonstration of what they have learnt. Teaching through Self Learning and Authentic Experiences was although not fully satisfactory was better managed.

Al-Aghbari's (2007) research on Social Studies of Omani teachers validates this study where his study also-similar to this - found that the application of IT was unstable; the study reported that teachers were on and off applying studentcentered teaching approach. He as well addressed that Social Study teachers did not fully comprehend the student-centered teaching approach, which in return impacted their teaching through the ITMs. The reasons behind the problem of implementing student centeredness is elaborated by Chiu and Whitebread (2011) who reported that teachers have a difficult time accommodating teaching through IT as a result of engrossed experience with the traditional teaching, social culture of the learners' parents and private tutors who practiced traditional teaching. This has contributed to the understanding of the reasons behind the problem of implementing teacher's centered approaches. Indeed this is brought out clearly in this research as well where Batool is working within a very traditional framework both at a personal capacity and in her workplace. She had to breakthrough her long believed methods of teaching and understandings of the roles of a learner and of a teacher. Hence, transforming her teaching practices may take some time as she eventually is enlightened on the real concept of ITS, empowered to change her practices, and finally emancipated with the extent and impact of ITS and AR altogether at post intervention stage.

In discussing the performance of Interactive Instructions based on Self Learning at the pre-intervention stage, Batool leaned very much towards a teacher-centered approach and her comprehension of Interactive Instruction were negligible. The improper conceptualization and therefore implementation of IT and its strategies was seen in the classes at pre-intervention observations. Batool shared that prior to taking up AR her aim was to convey knowledge and learners are to observe the knowledge, however, at the end of the intervention it is actually the opposite, where learners have the bigger role in exploring knowledge and her own role is to guide them. The learners have to seek knowledge by themselves in and out of the class practically and interactively with their peers.

At the intervention stage Batool began the lessons by introducing concepts and then allowing learner to learner through the discovery method, which is against constructivism according to Brooks (1990); however she at least managed to provide an explorative form of learning at the end of the intervention. Brooks (1990) presented how constructivist class looks like; to her in a normal traditional class the teacher introduces the concept followed by application and ends with further explanation when time permits. However, in a constructivist class she believes that it normally starts with learners' exploration and working with the given material to understand the concepts. Thus, Batool in this study allowed learners to initiate the practical part of the activity and not after observing the teacher but not personally understanding the concept. 
Learners got a chance to utilize discussed knowledge and experiences in their learning process without being given direct instructions on how to do so, or being made to read from written instructions was practiced prior to preintervention. In this situation it could be said that a Self Learning discovery element was being encouraged in the class and not only searching for information and presenting in the class. Thus, the enactment of the "Practical Application" based on discovery instruction was improved. This result confirms Blanchard's (2006) report that teachers' poor understanding of inquiry based instruction leads to failing in their enactment. It is also confirmed Nind (2000) study, which proved gaining an understanding of ITSs did support the right implementation of the methods amongst female special education teachers.

Batool's limited understanding of the teacher's role was that a teacher has to present the learning activities and give instructions and notes and only intervene at the end of the activity when there is a common mistake made by the group. This understanding negatively impacted her performance of Group Learning method. In her first statement she did not communicate the concept of facilitating and guiding learners, in the second she mentioned the idea of directing learners, in the third she mentioned that her role appears only towards the end of the activity when there is a common mistake. This kind of understanding reflected her role throughout the study however with less impact compared to the intervention stage. It is true teachers should be providing learners with opportunities for self learning but not to intervene only towards the end of the learning process or only when there is a common mistake. In this situation a correction can create disappointment in the learners as they have spent most of their class time in thinking and solving the problem, thus learning will not have be achieved effectively. Alternatively when learners are faced with obstacles and are making mistakes a teacher should turn it into an opportunity for learning.

In discussing the shift in enacting Group Learning, Batool appreciated the improvement and the shifting in group-work management as she recognized that at the pre-intervention phase she was avoiding teaching through Group Learning and it was a burden to her. Despite Batool being satisfied with her improvement in managing Group Learning in comparison to the preintervention phase and noting that her learners have become better, in reality there was not much change. This is possibly due to two reasons, first is the incomplete participant understands of the role of a teacher in IT and poor group management skills; while the second factor is the poor learners' skills in working in Group Learning.

In this study, learners' reflection on what they learned and presented in their work independently whether individually or in groups was an area where Batool did not make much changes to her instruction methods. The only time learners were given a chance to reflect was in the third intervention observation teaching class, where she gave them few minutes to discuss among themselves the difficulties they faced as they worked in groups. Learners' reflection on what is learnt is the fundamental aspect of any learning cycle (Brooks, 1990). Watkins, Carnell, Lodge, Wagner and Whalley (2002) stated that without reflection learning is lost. Therefore, in IT\&L teachers should allow room for learners to take part in all the processes of the activity during a lesson, get time to articulate what they learnt and the teacher facilitates the learners' role. 
In terms of presentation, learners were allowed some scope to present their work with Batool tightly controlling the discussion and still contributing to conclusions as documented in the second intervention observation. The most noticeable improvement in providing opportunities for learners to present their work was observed only twice in the third and seventh observation where Batool guided but did not contribute her views and conclusions. In the final observation, however, the learners were deprived of the opportunity again which proved the instability application of IT elements. Prince and Felder (2006) have emphasized the importance of the learners' role in presenting what they learnt and stimulating the discussion among them for a better understanding and interaction. According to Tobler et. al., (2000) promoting behavioural life skills requires group learning activities and adopting learners' self evaluation method among other procedures, which could be achieved in the presentation.

One of the skills in administering teaching through group-work is scaffolding and providing learners with feedback as the teacher rotates among groups. Feedback, according to Knight (2003), is a building block of the intervention process; it has significant impact on student achievement. It is part of the teaching process that comes as a result of learners' performance, the aim is motivation and minimizing the discrepancy between what is understood and supposed to be understood (Hattie \& Timperley, 2007). Hence, it is an important element of teaching, which is missed out by Batool in this study and thus the learners were at a disadvantage.

At the pre-intervention phase Batool did not provide any feedback to the learners as she circulated between the groups, instead she tended to hasten the learners in finishing their work quickly to ensure completing within class time, except for one observation where she praised the learners for being first in doing their work. During the intervention stage Batool tried her best to provide feedback; however, she missed several opportunities of providing feedback and scaffolding in a right way. As learners were in a group making a funnel, instead of asking learners to validate their work - why did they use a paper to make a funnel for decorating Hannah - and whether it could be used to fill Hinaa paste she gave the explanation for their work. In fact, Batool herself used the wrong example of a funnel as she explained it, she used a paper funnel when it should actually have been a plastic. Here, she mismanaged her role as a facilitator who creates an opportunity to achieve the desired learning outcome. According to Hattie and Timperley (2007) giving feedback to the learners helps seek strategies independently to complete the task and reach their goal.

Missing of scaffolding learners also happened when learners in a group did not do the task, and Batool commented nothing during her rounds to observe group work. Further, even during the learners' presentation time Batool did not find out the reason for learners' failure to do the task. Quintana et. al., (2004) argues on the importance of scaffolding learners, as they go through the learning process, based on the Problem-Based and Inquiry Learning methods. They pointed out that scaffolding is needed to support learners going through the process of sense making, running their exploration and solving their problems; it also encourages learners to clear their thoughts and reflect on their learning. Hence, in the situation where Batool found that learners did not know how to do a task, she should have provided further explanation or put them in another group that could support them to achieve the learning objective. However, the learners were deprived of a proper learning situation. 
Overall, what was observed in this study from the pre-intervention phase up to the final intervention observations was that the learners were still not working in a cooperative group as it should be. Batool asked the learners to take roles and responsibilities, distributing the roles. However, the response from the learners was poor. Learners argued amongst each other over roles and worked in a competitive way rather than in a supportive and cooperative way. Christie, Tolmie, Thurston, Howe and Topping (2009) pointed out similar finding, although learners are in groups they are observed to be working independently and with poor interaction skills and thus interactive learning in groups fails to take place. The consequences of this behaviour were discussed by Blatchford et. al., (2003) when they see that when learners sit together in a group, they do not function cooperatively as they can easily be distracted from the task given and engage in social talk. This situation was observed and proved by the learners of this study, the right interaction did not take place and learners were distracted and obviously the opportunities for learning were missed.

According to Zakaria and Iksan (2007) teachers and learners in Group Learning face challenges due to teachers' poor knowledge and management of different types of cooperative learning as well as learners' poor skills to work cooperatively.

In this study learners worked in groups activities that required materials in all the observations attended by the researcher. However, there was always a problem with provision of sufficient and right materials and therefore created arguments and chaos within the groups and revealed the poor skills of learners to work in groups which was acknowledged by Batool. Hence, this problem contributed to poor enactment of Group Learning and learners missed out on the benefits of positive interaction. Reddy and James (2003) and later Rooth (2005) reported on teachers struggling with enacting ITSs due to inadequacy of proper teaching resources. In the Omani context, Murphy et. al., (2006) reported that this was one of the factors that contributed to science not being taught interactively through practice and discovery.

To solve the problem of learners' conflict in groups learners should establish communication rules, working processes and the role of each member should be defined. Finally, they recommended that an efficient group leader should display leadership skills. Hence, learners should be taught group work skills before asking them to work in groups an aspect that is not considered in Omani schools. Learners are told to work in groups and told what to do but there are not provided with sufficient training on how to achieve this. Learners who are new or unfamiliar with group learning will not know how to act; hence, assigning responsibility of subtasks to learners should be gradually transferred from teachers to learners.

Batool distributed responsibility in the group in different intervention observation sessions. However, Batool often assigned the task for the group learning with no follow-up for confirmation. When learners were assigned the responsibility they did not fulfill it; when they were asked to distribute responsibility among themselves they did not do it and if they did, they did not adhere to it. Therefore, building on the recommendations of and James et. al., (2002) learners with such characteristics need a teacher to distribute the responsibility and make sure it is agreed and followed upon by the learners. 
Blatchford et. al., (2003) reported that in UK, studies show a lack of planning in terms of teaching through group-work as a consequence many teachers find it difficult to take-up this method. Zakaria and Iksan (2007) presented further challenging for teachers adopting cooperative learning in teaching, for them the main reasons are: (1) the method needs much time for teaching material preparation, (2) it wastes a lot of teaching time, (3) not trusting learner's ability to learn by themselves, (4) teachers lacking with necessary skills to manage group work and learners lacking skills to work in groups.

In this study too, the teacher had problems with group work skills, in part due to her own struggle with shifting from her previous method of dictating group work and partly due to the characteristics of the learners who were unable to be cooperative. It should be recognized that the pre-intervention method that Batool used daily in her work with the learners shaped the character of the learners. Thus, when they are suddenly given responsibility for the work of the group, when before they had none, it required a paradigm shift even for the learners. There is suddenly too much freedom of thought to deal with, as suddenly the teacher who is used to dictating and is now pushing herself admirably to change this way of thinking, it is also about dealing with this freedom given to students who did not have it before. It must be recognised that it was a learning process for both parties and therefore it should be expected that there will be a phase when both become aware of their weaknesses and strengths and eventually together develop a co-operative pattern.

In discussing the enactment of teaching through Authentic Experiences, Batool showed correct understanding of teaching through Authentic Experiences throughout the study. Moreover, she conveyed that she had no problem in indentifying and selecting real learning experiences. However, at the practical teaching level through Authentic Experiences had some drawbacks in terms of application of usage of real materials or utilizing real situations, this was seen at both the pre-intervention and intervention stages. Batool explained that she had contradictive feelings, that she sometimes feel comfortable in selecting the experiences for teaching but when it came to application she was not happy, or vice versa. For example when Batool was teaching learners about making a bandage, she had to use paper instead of a fabric.. This can produce a sense of falseness in teaching a life-application skill.

In the post-intervention stage Batool acknowledged her comfort in selecting and applying them in her teaching. She now appreciated teaching through IL and her perception toward Living Skills subject. Her perception towards the subject had changed from her having considered it to be insignificant to now having value. However, Batool was seen not to consider the authentic application of a learning activity taught as she was displaying the funnel for Hinaa decoration. This results in passive reception of information which made learners using paper to make a funnel instead of a plastic material. This situation has contradicted Kolb, Boyatzis and Mainemelis (2000) recommendation of learning through experiential learning which calls for learners to be engaged vigorously in: (1) real learning contacts; (2) reflecting

on the learnt experience; (3) applying inductive reasoning; analyzing, understanding, explaining and incorporating what was learnt into logic theory that guides action; and (4) finally considering ways of transforming what was learnt into action. 
A gaining advantage of intervention stage is seen at how the teacher managed to take a positive action to provide a conducive learning environment. According to Oman's educational policy specific learning activities are to be taught in classrooms that provide autonomy to teachers in modifying their teaching and learning environments that benefits the learners MoE (2008). Although Batool claimed to follow and adhere to the teacher's guide activities, at the intervention stage she positively managed the content in the curriculum and made the necessary adjustments to achieve the desired learning results that matched with her learners' needs. As an example, although the text book presented a certain activity to be performed she allowed learners the choice to select their own accessory to make.

Vighnarajah, Luan and Abu Bakar (2008) report that several studies demonstrate that for effective learning to take place a learning environment that emulates the real-world has proven to be more successful in achieving educational success rather than the traditional passive classroom method. In this study when Batool made a shift from the traditional teaching and learning environment to a learning environment that encourages active learners' participation in the learning process the result was learners enjoyed the lessons, interacted well with each other, obviously benefited from the lessons and looked forward to more such classes and this in turn gave her professional satisfaction.

According to Brooks J and Brooks M (1993), a constructivist teacher whose aim is to support learners personally initiate the learning process is a very demanding task. Indeed Batool in this study also found this to be the case; she struggled initially but eventually was able to see the changes and the ensuing benefits of such an effort. During a training programme conducted by this researcher on IT at Batool's school and the community, a visible change and confidence was displayed by Batool at the training and this was six months after the conclusion of fieldwork. Batool demonstrated a Living Skills lesson presenting IT aspects and spoke on how her experience with AR improved her instructional skills.

In summing up, despite the initial struggles faced by Batool she showed considerable improvement in her practice of IT from the pre-intervention and the early stage of intervention to post-intervention. This could be clearly observed in the "Practical Application" sessions where Batool had begun the process of shifting her practice of dictating a class to achieving a more learner-centered atmosphere. However, for Batool to continue on this scale of progress she needs more enhancement and support for the changes to be enduring. Moyles et. al., (2001) reported that despite improvements taking place with literacy teachers understanding of IT in England's schools; teachers needed more opportunity to improve their application of IT. The same applies to Omani teachers as well.

\section{Teacher's experience with AR}

The second aspect of this study was to explore teacher's perception and view on taking up AR to improve her teaching through "Practical Application" based on the learner-centered approach; the focus was on how she perceived the experience and the challenge she faced. Hence, the final two research question are discussed and presents Batool's own accounts of the challenges and achievements gained as a result of engaging in AR. My interpretation as a 
result of guiding and observing Batool throughout the implementation process will also be shared.

\section{Challenges}

Teachers facing challenges as they engage in AR has been addressed by many researchers such as Greene et. al., (2008), Christenson et. al., (2002) and Alwan (2000) among others. In this study, the time aspect was perceived to be the greatest obstacle; Christenson et. al., (2002), Zeichner (2003) and recently Sales, Traver, and García (2011) documented the same findings. Time factor was the recurrent constraint reason for engaging in AR. Consequently, this impacted on her writing of reflection notes and action plan, data analysis, reading and researching. Her notes and discussions with me conveyed the message of being so stressed in school to the extent that sometimes she had no free lesson time to do her work preparation with a tight schedule of 20 classes, and no time at home. The issue of time was also a factor in teachers dropping out of in the middle of the study process and male participants refused to join citing time constraints at the very beginning of the study.

Despite this time constraint issue Batool recognised the value of AR and showed interest in learning and considers it in the future. Moreover, she conveyed that although the district training is useless she does not prefer taking up PPD because of the time issue and not getting a support from the school or the district. Sales, Traver, and García's (2011) study confirm similar findings where they reported that teachers complained about not having enough time and space to reflect and innovate due to routine work that are not related directly to teaching tasks.

Teachers' struggling with the application of AR because of lack of research skills was reported by Christenson at al. (2002), Zeichner (2003), O'Connor, Greene and Anderson (2006), Degago (2007), Al-Hadhrami (2008). Zeichner (2003) communicated that although many teachers appreciated the intellectual gains from AR there were some challenging issues, such as logistics, research skills and school social relationship frustrations hampered the application of AR.

In the Omani context, Al-Hadhrami (2008) confirmed that the problem of poor research skills, lack of support and time are challenges that teachers face when they want to take up AR. The report is in line with the findings of this study. The weakness in research skills is mainly contributed by poor teacher preparation in research skills as reported by Batool in this study and confirmed by Al-Hadhrami (2008) report.

From the different statements made by Batool it could be concluded that the lack of information and resources, teaching overload, poor administrative and peer support and the teachers own quality of research skills acted as a constraint in her experience. Additionally, she lacked family support which is important to a human being looking for ways to make personal changes. The findings of this study are also consistent with AlMamammiria's (2009) study on the requirements of AR and organizational climate at schools of post-basic education in Oman. This aspect comes out clearly where she discusses the issue of poor organizational support in terms of social, emotional and academic in conducting AR in Omani schools. 
Due to these constraints Batool faced, she stated that the only reason that will encourage a teacher to engage in AR is her deep willingness and interest, without which it will be difficult to go on with the situation that schools operate now. This message is an important note for policy makers who are interested in making AR a PPD activity in schools.

\section{Perceptions toward AR after going through it.}

Batool conveyed that she was ignorant of AR and that AR was a completely new learning area in her professional experience. Degago (2007) reported similar findings with Ethiopian pre-service teachers who were first time action researchers. The transformation was from not having any information about AR as reported from the pre-intervention to Batool being able to satisfactorily define its process and the objective of doing it. In addition she also appreciated going through this the experience and completing it. Batool was able to communicate the objectives and advantages of taking up AR and compared it with other forms of training and appreciated it over other forms provided by the in-service system. She presented her appreciation of the practical aspect of conducting AR, the context of classroom application and the opportunity that it allows one to conduct deep study with regard to the case of concern. Moreover, the continuous guidance given to her during the AR process was appreciated; this is something that does not happen in normal trainings. Kervin (2003) communicated his unproductive experience with training while he was a teacher which supports Batool claim. He conveyed that he would come back from the training with impressive ideas but no adequate opportunities for implementation. Batool as well perceived the influential aspect of contextual nature of AR which is supported by Kervin (2003) who saw that for teachers to make a change in their professionalism they are supposed to employ critical and experimental methods contextual to their teaching environment.

The reflection as a process that supports identification of a problem was appreciated by Batool as she stated that she gained a lot from reviewing what she was doing. Her claim is approved by Brookfield (2005) who saw reflective learning is the process of critically looking at the information and experience one is exposed to.

A teacher engaging in AR benefits in two ways (1) improving his/her skills; and (2) learners' better their learning. Nuntrakune et al. (2009) also confirmed that AR benefits teachers' instruction and impacts learners' learning. Batool in this study stated that she as a teacher benefited from engaging in AR, but she did not acknowledged learners' benefits especially in the learning outcome. On the other hands she reported on learner's point of view of enjoying learning better as they were taught through ITMs.

According to Johnson (2008) AR is a systematic approach that helps teachers reflect on their problems and develop solutions for a particular concern area. Batool in this study mentions that recognizing her weaknesses in a systematic way guided her improvement in instructional skills and opened a path to more learning.

This study also found that Batool gained not only professional improvement but it also helped her recognise her weaknesses in her family interaction patterns and was able to make beneficial changes to improve her family relationships as well. The contributions of AR on a personal scale was 
acknowledged by Reis-Jorge (2007) and Al-Harthy (2010).

Socialization was added to the benefits she presented as a result of doing AR. This confirms the nature of many communities learning AR and qualitative researches which emphasize on positive social relationships. Pitts and Miller-Day (2007) reported that relationships between researchers and participants do progress, and that they can be pleasing and lasting. Moreover, it is an important aspect that contributes to increasing trustworthiness of a qualitative account. Eide and Kahn (2008) presented the close relationship that developed between the researcher-nurse- and the participant patient where the patient was longing to see. Eide and Kahn (2008) examined researcher's dilemma, in a nursing school setting, when the interaction between researcher and participant involves a degree of therapeutic interaction for the participant. This was noticed in this study as well, although this was not a nursing school setting, in this case, I was also a guide to the only participant who took part in a rather rigorous study. Batool was alone in her research and was sometimes faced with issues that disturbed her application of AR. So the relationship that developed between Batool and me and at times acquired a psychological dimension where I sometimes became a counselor and friend.

In Islam the reflective process is key to becoming a better person, Batool reported that since engaging in AR where reflection is key to improvement she has also understood the meaning of accountability for ones actions in Islam and why reflection is obligatory. According to the Islamic Society of North America, 2010, Religion and Society Program, an experiential workshop on US and Arab world dialogue, reflection contributed positively to religious conceptions. Participants from three religious backgrounds - Muslim, Christian and Jewish - were requested to reflect on their pre-conceived notions of each other and found that this process helped change their behaviour and attitude from within.

According to Waters-Adams (2006) action researchers heavily work on their own practice within their demands of space and time; thus providing flexibility in usage. Batool in this study acknowledged that AR can be a convenient way to improve and develop professionally and thus she encouraged other teachers to use AR in their own work.

The advantage of AR as a convenient professional development in terms of flexibility of duration was acknowledged by Batool. According to Waters-Adams (2006) action researchers heavily work on their own practice within their demands space and time. Batool's appreciation of the advantages she experienced allowed her to propose encouraging other teachers to take up AR.

\section{CONCLUSIONS AND RECOMMENDATIONS}

In conclusion, this study shed a light on the deeper responsibilities for teachers who are working under the principles of learner-centered approaches to have better conceptualization of IT to influence their practice. Moreover, training should be considering the practical aspect of classroom learning rather than only theoretical. Furthermore, for better use of ITSs there is a need for the teaching and learning resources to be well considered at the school level or the ministry level and not to be left for teachers and learners. Adding to that the Living Skills teacher's guide and learners' text book should be built 
on the philosophy of learner-centered approach that guides and encourages Self Learning. Teachers should be allowed time to reflect upon their teaching and be provided with practical training to develop their research skills. For this purpose, AR should be inculcated in all in-service training to enhance the performance of teachers.

\section{REFERENCES}

Al-Aghbari, S. Y. (2001). Su ūbāt tadrīs al-tafkìr fì al-marhalah al-thanāwiyyah fì Saltanah Oman min wijhah nadar al-mu alimin wa al-mu alimät wawad tasawwur wa muktarah li läjih $\bar{a}$ [Male and female teachers perception on the difficulties facing teaching History subject in secondary education and proposing a solution for it]. Unpublished master thesis, Sultan Qabos University (SQU), Oman.

AL-Aghbari, S. Y. (2007). Social Studies teaching in Oman: Teachers' concerns and levels of use in the adoption of student-centered teaching approach. Unpublished doctorate dissertation, Universiti Sains Malaysia. Retrieved from http://eprints.Usm. my/946 1/1/SOCIAL_STUDIES_TEACHING_IN_OMAN.pdf

Al-Hadhrami, K. K. M. (2008). Su ūbāt tanfị̣ al-bahth al-ijräiyyah. Dauriyyah altațīr al-tarbawi [Difficulties performing action researches]. Periodic Education Development. No 40, February. MoE, Oman.

Al-Harthy, S. S. (2008). Al- 'alãqah baina mu taqadãt mualimi al- ulūm hawla istikhdãm istrãtijiãt al-ta 'allum al-mabnī alã al-istikhsã wamumãrasãtihim aLiving Skillsafyyah lahã [The relationship between science teachers' attitudes towards the use of enquiry base teaching strategies and their class application]. Unpublished master thesis, SQU, Oman.

Al-Harthy, W. S. S. (2010). Khibarat wa mumãrasãt al-tanmiah al-mihaniyyah liba'dh mudìrì wa madãris al-ta alìm al-asãsī bisaltanah Oman [Personal professional development experiences and practices of some principals from cycle two of Basic Education schools in Sultanate of Oman]. Unpublished master theses, SQU, Oman.

Al-Hinai, A. M. (2007). The interplay between culture, teacher professionalism and teachers' professional development at times of change. Handbook of teacher education. 4152.

Al-Lamky, H. S. (2007). Madã Tanwi Mualimĩ Mãddah Al-mahãrãt Al-hayãtiyyah fi Istikhdãm Al-asãlīb Al-tadrīs Wal 'adawãt Al-ta qwìmiyyah fi Tadrīs Manãhij Alssaf Al-ssãbi al-asãsi [The extent to which life skills teachers use and alter teaching methods and assessment tools while teaching grad seven]. Unpublished research report, MoE, Oman.

Al-Jadidi, H. S. (2009). Teaching English as a foreign language in Oman: An exploration of English language teaching pedagogy in tertiary education. Unpublished doctoral dissertation. Retrieved from http://vuir.vu.edu.au/15216/.

AlMamammiria, S. N. M. (2009). Mutatalabãt buhūth al-amal wa al-manãkh altandimī, alsã 'id fi madãris al-ta alìm ma ba'd al-asãsī fí Sultanah Oman [Requierments for Action Researches and organization climate at the schools of Post-Basic education in the Sultanate of Oman. Unpublished master theses, SQU, Oman.

Al-Nofli, M. A. (2010). Students' perceptions about geography: A study of basic education school students in Oman. European Journal of Educational Studies, 16(1), 11-20.

Al-Sarmi, K. S. A. (2004). Su übāt tanmiah mustawayāt al-tafkīr al- ulyā fì mäddah al-tārìkh 
ladā talabah al-marhalah al-thānawiyyah min wajahah nadhar al-mu alimin wa almuwajihin [Difficulties facing the development of higher order thinking skills in History subject for secondary school students as seen by teachers and inspectors]. Unpublished master thesis, SQU, Oman.

Blanchard, M. (2006). Assimilation or transformation? An analysis of change in ten secondary science teachers following an inquiry-based research experience for teachers. Retrieved from ProQuest Digital Dissertations. (AAT 3232366)

Blatchford, P., Kutnick, P., Baines, E., \& Galton, M. (2003). Toward a social pedagogy of classroom group work. International Journal of Educational Research, (39), 153172.

Boler, T., \& P. Aggleton. (2005). Life skills education for HIV prevention: a critical analysis. London, Save the Children and Action Aid International. Retrieved from http:// www.actionaid.org/assets/pdf/life_skills_new_small_version.pdf

Brook, J. G. (1990). Teacher students: Constructivists forging new connections. Educational Leadership, (47), 68-71.

Brooks, J. G., \& Brooks, M. G. (1993). Becoming a constructivist teacher. In search of understanding: the case for constructivist classrooms. (chapter 9). Retrieved from http://www.pbs.org/teacherline/courses/inst335/docs/inst335_brooks.pdf

Brookfield, S. D. (2005). The power of critical theory for adult learning and teaching. Berkshire: Open University Press.

Brown, B. (2002). Improving teaching practices through action research. Doctoral dissertation. Retrieved from http://scholar.lib.vt.edu/theses/available/etd04152002$182022 /$ unrestricted/BethBrownDissertation.pdf.

Brown, H. T. (2005). Beyond constructivism: Exploring future learning paradigms. Education Today, (2), 1-11. Retrieved from http://www.bucks.edu/old_docs/academics/ facultywebresources/Beyond_const ructivism.pdf

Bulunuz, N., \& Jarrett, O. S. (2010). The effects of hands-on learning stations on building american elementary teachers' understanding about earth and space science concepts. Eurasia Journal of Mathematics, Science \& Technology Education, 6(2), 85-99.

Chiu, M \& Whitebread, D. (2011). Taiwanese teachers' implementation of a new 'constructivist mathematics curriculum: How cognitive and affective issues are addressed. International Journal of Educational Development, 31(2), 196-206.

Christenson, M., Slutsky, R., Bendau, S., Covert, J., Dyer, J., Risko, G., \& Johnston, M. (2002). The rocky road of teachers becoming action researchers. Teaching and Teacher Education, 18(3), 25 9-272.

Christie, D., Tolmie, A., Thurston, A., Howe, C., \& Topping, K. (2009). Supporting group work in Scottish primary classrooms: improving the quality of collaborative dialogue. Cambridge Journal of Education, 39(1), 141-156.

Coghlan, D., \& Brannick, T. (2005). Doing action research in your own organization. London; Thousand Oaks: Sage Publications.

Creative Associates International, Inc. (2006). Unpublished regional teachers reports, 788/2007, submitted to General Directorate for Curriculum Development-Oman.

Degago, A. T. (Spr, 2007). A First-Timer's impressions of engaging in action research: A case in Ethiopian pre-service teacher education. Action in Teacher Education, 29(1), 7180 . 
Denzin, N. K., \& Lincoln, Y. S. (2000). Introduction: The discipline and practice of qualitative research. In Denzin, N.K. \& Lincoln, Y.S. (Eds.), Handbook of Qualitative Research. Thousand Oaks, CA: Sage.

Eide, P., \& Kahn, D. (2008). Ethical issues in the qualitative researcher-participant relationship. Nursing Ethics, (15)2, 199-207. DOI: 10.1177/0969733007086018.

Faour, M (2011). The Importance of education in the Arab World. Retrieved June $28^{\text {th }}, 2012$. http:/ /carnegieendowment.org/20 11/12/01/importance-ofeducation-in-arabworld $/ 8 \mathrm{kpl}$

Ferrance, E. (2000). Themes in Education: Action Research. Retrieved from http://www.lab.brown.edu/pubs/themes_ed/act_research.pdf

Fidishun, D. (2000). Andragogy and Technology: Integrating Adult Learning Theory as we teach with

Gordon, R., Kane.T., \& Staiger, D. O. (2006). Identifying effective teachers using performance on the job. Retrieved from http://www.brookings.edu/ /media/ Files/rc/papers/ 2006/04educationgordon/ 2006 04hamilton_1 .pdf.

Goodnough, K. (2001). Teacher development through action research: A case study of an elementary teacher. Action in Teacher Education, 23(1), 37-46.

Greene, C., O’Connor, K., \& Anderson, P. (2008). Action research goes to school: Encouraging high quality teaching through personal development. Retrieved from http://www. isetl.org/conference/presentation.cfm?pid=820.

Greenwood, D, J., \& Levin, M. (2007). Introduction to action research: Social research for social change. Thousand Oaks, Calif: Sage Publications.

Hattie, J., \& Timperley, H. (2007). The power of feedback. Review of Educational Research March, (77)1, 81-112.

Islamic Society of North America. (2010). Reflections and experiences of religion and society. Retrieved from http://www.nationalpeace.org/files/Reflections \% $\% 2020$ Experiences $\% 20$ of $\% 20$ Religion $\% 20$ and $\% 20$ Society.pdf

James, E. A., Milenkiewicz, M.T., \& Bucknam, A. (2008). Participatory action research for educational leadership: Using data-driven decision making to improve schools. Thousand Oaks, CA: Sage Press.

James, R., McInnis, C. \& Devlin, M. (2002) Assessing Learning in Australian Universities. Retrieved from http://www.cshe.unimelb.edu.au/ assessinglerning/docs-/docs/ Group.pdf.

Johnson, A, P. (2008). A short guide to action research. USA: Person Education, Inc.

Kervin, L. (2003). A model for in-school teacher professional development: Extending on action research. Retrieved from http://www.aare.edu.au/03pap/ker03 3 52. pdf.

Knight, N. (2003). Teacher feedback to students in numeracy lessons: Are students getting good value? SET: Research Information for Teachers, 3, 40-45.

Knowles, M. S. (1975). Self-directed learning: A guide for learners and teachers. New York: Association Press.

Kolb, D. A., Boyatzis, R. E., \& Mainemelis, C. (2000). Experiential learning theory: Previous research and new directions. In R. J. Sternberg \& L. F. Zhang (Eds.), Perspectives on cognitive, learning, and thinking styles (227-247). Mahwah, NJ: Lawrence Erlbaum. Retrieved from http:/www.d.umn.edu/ kgilbert/educ5 165-731 / Readings/experiential-learning-theory.pdf 
Lombardi, M. (2007). Authentic learning for the 21st Century: An overview. EDUCA USE Learning Initiative. Retrieved from http://www.connect. educause.edu/lib- rary/ abstract/AuthenticLearningfor/3 9343.

Merriam, S. B. (1998). Qualitative research and case study applications in education. San Francisco: Jossey-Bass.

Ministry of Education [MoE]. (2004a). National report on quality education Oman. Part one. Retrieved from http:// www.ibe.unesco.org/International/ICE47/Engli- sh/Natreps/ reports/oman_part_1.pdf

MoE. (2008). Kitāb Al-mu 'allim limāddah al-mahārāt al-hayātiyah lil-ssaff al- āshir [Teacher's guide for life skills subject grade ten]. Oman: Oman enterprise for news paper, publishing and advertizing.

Moyles, J., Hargreaves, L., Paterson, F., \& Esarte-Sarries, V. (2001). The development of primary teachers' understanding and use of interactive teaching. Paper presented at the British Educational Research Association Annual Conference,

Murphy, C., Ambusaidi, A., \& Beggs, J. (2006). 'Middle East meets West: Comparing children's attitudes to school science. International Journal of Science Education, 28(4), 405-422.

Nind, M. (2000). Teachers' understanding of interactive approaches in special education International Journal of Disability, Development and Education, 47(2), 183-199.

Nuntrakune, T., Nason, R., \& Kidman, G. (2009). Two Thai teachers' perceptions of cooperative learning. Queensland University of Technology. Retrieved from http:// www.aare.edu.au/08pap/nun08573.pdf.

O'Connor, K. A., Greene, H. C., \& Anderson, P. J. (2006). Action research: A tool for improving teacher quality and classroom practice. Retrieved from http://oar. nipissing- u.ca/pdfs/v911e.pdf.

Pitts, M. J., \& Miller-Day, M. (2007). Upward turning points and positive rapport development across time in researcher-participant relationships. Qualitative Research, 7(2), 177201.

Prince, M. J., \& Felder, R. M. (2006). Inductive teaching and learning methods: Definitions, comparisons, and research bases. Journal of Engineering Education 95(2), 123-38.

Quintana, C., Reiser, B. J., Davis, E. A., Krajcik, J., Fretz, E., Duncan, R. G.,... Soloway, E. (2004). A scaffolding design framework for software to support science inquiry. Journal of the Learning Sciences, 13, 337-3 86.

Reis-Jorge, J. (2007). Teachers' conceptions of teacher-research and self-perceptions as enquiring practitioners-A longitudinal case study. Teaching and Teacher Education 23, 402-417.

Reddy, P., \& James, S. (2003). Programming for HIV prevention in South African schools: a report on program implementation. Cape Town: South African Medical Research Council. Retrieved from http://www.popcouncil.org/ horizons/ressum/schools/sa/ sa key.html.

Rooth, E. (2005). An investigation of the status and practice of life orientation in South African schools in two provinces. Unpublished doctoral dissertation. Retrieved from http://etd.uwc.ac.za/usrfiles/ modules/etdinit1 920117791 5444.pdf.

Sahlberg, P. (2008). The more you talk, the more you learn: Missing conditions for cooperative learning in secondary schools. Eur. J. Educ., 43, 15 1-172.

Sales, A., Traver, J., \& García, R. (2011). Action research as a school-based strategy in 
intercultural professional development for teachers. Teaching \& Teacher Education, 27(5), 911-919.

Tobler, N, S., Roona, M, R., Ochshorn, P., Marshall, D, G., Streke, A, V., \& Stackpole, K, M. (2000). School-Based adolescent drug prevention programs: 1998 Meta-Analysis. Journal of Primary Prevention, 20(4), 275.

UNESCO. (1999). EFA 2000 Assessment Report. Retrieved from http://www.unesco.org/education/wef/countryreports/oman/contents.html.

UNESCO. (2008). Gender-responsive life skills-based education. Advocacy Brief. Bangkok: 20 pp. Retrieved from http://unesdoc.unesco.org/ images/0017/001781/178 125e. pdf.

Vighnarajah, Luan, W. S., \& Abu Bakar, K. (2008). The shift in the role of teachers in the learning European. Journal of Social Sciences (7)2.

Waters-Adams, S. (2006). Action Research in Education. Retrieved from http://- www.edu. plymouth.ac.uk/resined/actionresearch/arhome.htm.

Watkins, C., Carnell, E., Lodge, C., Wagner, P., \& Whalley, C. (2002). Effective learning. ISIN Research Matters, 17.

Windschitl, M. (2004). Folk theories of “inquiry:” how pre-service teachers reproduce the discourse and practices of a theoretical scientific method. Journal of Research in Science Teaching, 41(5), 481-5 12.

World Bank. (2006). World report 2007 on development and the next generation. Published by World Bank Publications. Retrieved: http://books.google.com/-books?id=xR9IcNwrQUC\&pg=PA75\&lpg $=\quad$ PA75\&dq=interactive+teaching + methods $+\quad$ in + Lif $\mathrm{e}+$ Skills\&source=bl\&ots=AXe FcUB8P\&sig=oqgBtUPmhq3WNKMIF 61 Yk8OccgY\&hl=en\&ei=8USfSf7bCca.

Zakaria, E., \& Iksan, Z. (2007). Promoting cooperative learning in science and mathematics education: A Malaysian perspective. Eurasia Journal of Mathematics, Science \& Technology Education, 3, 35-39.

Zeichner, K., M. (2002). Teacher research as professional development for P-12 educators in the USA. Educational Action Research, 11(2), 301-326 